\title{
Additional Gastrectomy after Non-Curative Endoscopic Submucosal Dissection for Early Gastric Cancer
}

\author{
Yeon Soo Chang, M.D., Ph.D. \\ Department of Surgery, Eulji Medical Center, Eulji University College of Medicine, Seoul, Korea
}

\author{
Corresponding author \\ Yeon Soo Chang \\ Department of Surgery, Eulji Medical Center, Eulji University College of Medicine, 68, Hangeulbiseok-ro, Nowon-gu, Seoul 01830, Korea \\ Tel: +82-2-970-8688, Fax: +82-2-970-8227, E-mail: cutdown@eulji.ac.kr
}

See the article Impact of the Endoscopic Submucosal Dissection on Early Postoperative Outcome after Additional Gastric Resections for Early Gastric Cancer. J Min Invasive Surg. 2016 March; 19(1);14.

This is an Open Access article distributed under the terms of the Creative Commons Attribution Non-Commercial License (http:// creativecommons.org/licenses/by-nc/4.0/) which permits unrestricted non-commercial use, distribution, and reproduction in any medium, provided the original work is properly cited.
Copyright (C) 2016 The Journal of Minimally Invasive Surgery. All rights reserved.
Endoscopic Submucosal Dissection (ESD) is widely accepted as one of the treatment options for early gastric cancer (EGC) with negligible risk of lymph node metastasis by improvement in techniques and endoscopic devices. In addition, oncologic outcomes of ESD for EGC have been proved comparable with standard gastrectomy. ${ }^{1-4}$ According to Japanese Gastric Cancer Treatment Guidelines, ${ }^{5}$ ESD is recommended only for patients who meet the criteria (absolute and expanded) due to risk of residual cancer and lymph node metastasis. Curative ESD is defined as; En-bloc resection, negative lateral and vertical resection margin, no lymphovascular invasion and (a) tumor size $>2 \mathrm{~cm}$, differentiated, pTla without ulcer or (b) tumor size $\leq 3 \mathrm{~cm}$, differentiated, pTla with ulcer or (c) tumor size $\leq 2$ $\mathrm{cm}$, undifferentiated, pTla with ulcer or (d) tumor size $\leq 3 \mathrm{~cm}$, histologically of differentiated, pT1b (SM1, <500 micron from the muscularis mucosae) by pathologic findings. Resection that does not satisfy any of the above criteria is considered non-curative. ${ }^{5}$

Additional surgery is usually performed for patients with non-curative ESD. But necessity of additional gastrectomy after non-curative ESD is still controversial. There are reports which suggest that close observation might be acceptable for some selected patients ${ }^{6,7}$ and others reported the needs and survival benefit of additional surgery depending on margin involvement, histologic type and lymphovascular invasions. ${ }^{8-11}$ Careful consideration should be given regarding patients' age, conditions and underlying diseases in the selection of ESD and surgery. ${ }^{9,12}$

ESD makes large iatrogenic ulcer with electric coagulation and it takes more than 4 8 weeks for healing. This ulcer can cause edema, fibrosis and adhesions of both stomach and surrounding tissues. Therefore ESD may increase surgical difficulties for additional gastrectomy as well as the risk of complications. ${ }^{13}$ This study showed no significant influence of ESD on additional gastrectomy. Several studies ${ }^{14-16}$ support similar results but also point that adhesion may result in difficult surgery and greater blood loss, and intended operative procedure can be changed due to contraction of the ESD scar near pylorus or cardia. ${ }^{13-15,17}$

As all we know, laparoscopic gastrectomy has become standard treatment for early gastric cancer. Laparoscopic gastrectomy with adequate lymph node dissection can be safely applied for patients with non-curative ESD regarding postoperative complications and oncologic outcomes. ${ }^{14,16}$ 
Authors compared the early postoperative outcomes according to the interval between ESD and additional gastrectomy. No established principal exists regarding ideal timing of surgery after ESD. We can refer to the result of one study which reported that about 1 month after ESD might be optimal for better surgical results without affecting the oncological outcomes. $^{13}$

Finally, it is important to select the patients with noncurative ESD for additional gastrectomy according to the risk of residual cancer and lymph node metastasis. Also, the surgeon have to keep in mind that scar and surrounding fibrosis of previous ESD can worsen the postoperative outcome and to secure sufficient safety margin from the lesion.

\section{REFERENCES}

1) Asano M. Endoscopic submucosal dissection and surgical treatment for gastrointestinal cancer. World J Gastrointest Endosc 2012;4:438-447.

2) Cho JH, Cha SW, Kim HG, et al. Long-term outcomes of endoscopic submucosal dissection for early gastric cancer: a comparison study to surgery using propensity score-matched analysis. Surg Endosc 2015. (in press).

3) Kondo A, de Moura EG, Bernardo WM, et al. Endoscopy vs surgery in the treatment of early gastric cancer: Systematic review. World J Gastroenterol 2015;21:13177-13187.

4) Sun $\mathrm{K}$, Chen S, Ye J, et al. Endoscopic resection versus surgery for early gastric cancer: a systematic review and meta-analysis. Dig Endosc 2015. (in press).

5) Japanese Gastric Cancer Association. Japanese gastric cancer treatment guidelines 2010 (ver. 3). Gastric Cancer 2011;14:113123.

6) Yamanouchi K, Ogata S, Sakata Y, et al. Effect of additional surgery after noncurative endoscopic submucosal dissection for early gastric cancer. Endosc Int Open 2016;4:E24-29.

7) Choi JY, Jeon SW, Cho KB, et al. Non-curative endoscopic re- section does not always lead to grave outcomes in submucosal invasive early gastric cancer. Surg Endosc 2015;29:1842-1849.

8) Kim ER, Lee H, Min BH, et al. Effect of rescue surgery after noncurative endoscopic resection of early gastric cancer. Br J Surg 2015;102:1394-1401.

9) Koide N, Takeuchi D, Suzuki A, Ishizone S, Miyagawa S. Additional gastrectomy after endoscopic submucosal dissection for early gastric cancer patients with comorbidities. Int J Surg Oncol 2012;2012:379210.

10) Lee JH, Kim JH, Kim DH, et al. Is Surgical Treatment Necessary after Non-curative Endoscopic Resection for Early Gastric Cancer? J Gastric Cancer 2010;10:182-187.

11) Toyokawa $\mathrm{T}$, Ohira $\mathrm{M}$, Tanaka $\mathrm{H}$, et al. Optimal management for patients not meeting the inclusion criteria after endoscopic submucosal dissection for gastric cancer. Surg Endosc 2015. (in press).

12) Heo J, Jeon SW. The clinical significance and management of noncurative endoscopic resection in early gastric cancer. Clin Endosc 2013;46:235-238.

13) Kim MJ, Kim JH, Lee YC, et al. Is there an optimal surgery time after endoscopic resection in early gastric cancer? Ann Surg Oncol 2014;21:232-239.

14) Ebihara $Y$, Okushiba S, Kurashima $Y$, et al. Totally laparoscopic gastrectomy for gastric cancer after endoscopic submucosal dissection: a propensity score matching analysis. Langenbecks Arch Surg 2015;400:967-972.

15) Kawata N, Kakushima N, Tokunaga M, et al. Influence of endoscopic submucosal dissection on additional gastric resections. Gastric Cancer 2015;18:339-345.

16) Kwon HY, Hyung WJ, Lee JH, Lee SK, Noh SH. Outcomes of laparoscopic gastrectomy after endoscopic treatment for gastric cancer: a comparison with open gastrectomy. J Gastric Cancer 2013;13:51-57.

17) Akagi T, Shiraishi N, Hiroishi K, Etoh T, Yasuda K, Kitano S. Case series of intra-abdominal adhesions induced by artificial ulceration after endoscopic submucosal dissection before additional laparoscopic gastrectomy. Gastrointest Endosc 2010;72:438-443. 